\title{
THE INFLUENCE OF DIFFERENT LEVELS OF DATA DETAIL ON LAND USE CHANGE ANALYSES: A CASE STUDY OF FRANCISCAN CADASTRE FOR A PART OF THE PANNONIAN HILLS, SLOVENIA
}

\author{
Jennifer Deriaz ${ }^{1}$, Rok Ciglič², Mateja Ferk³ ${ }^{3}$ Dénes Loczy ${ }^{4}$
}

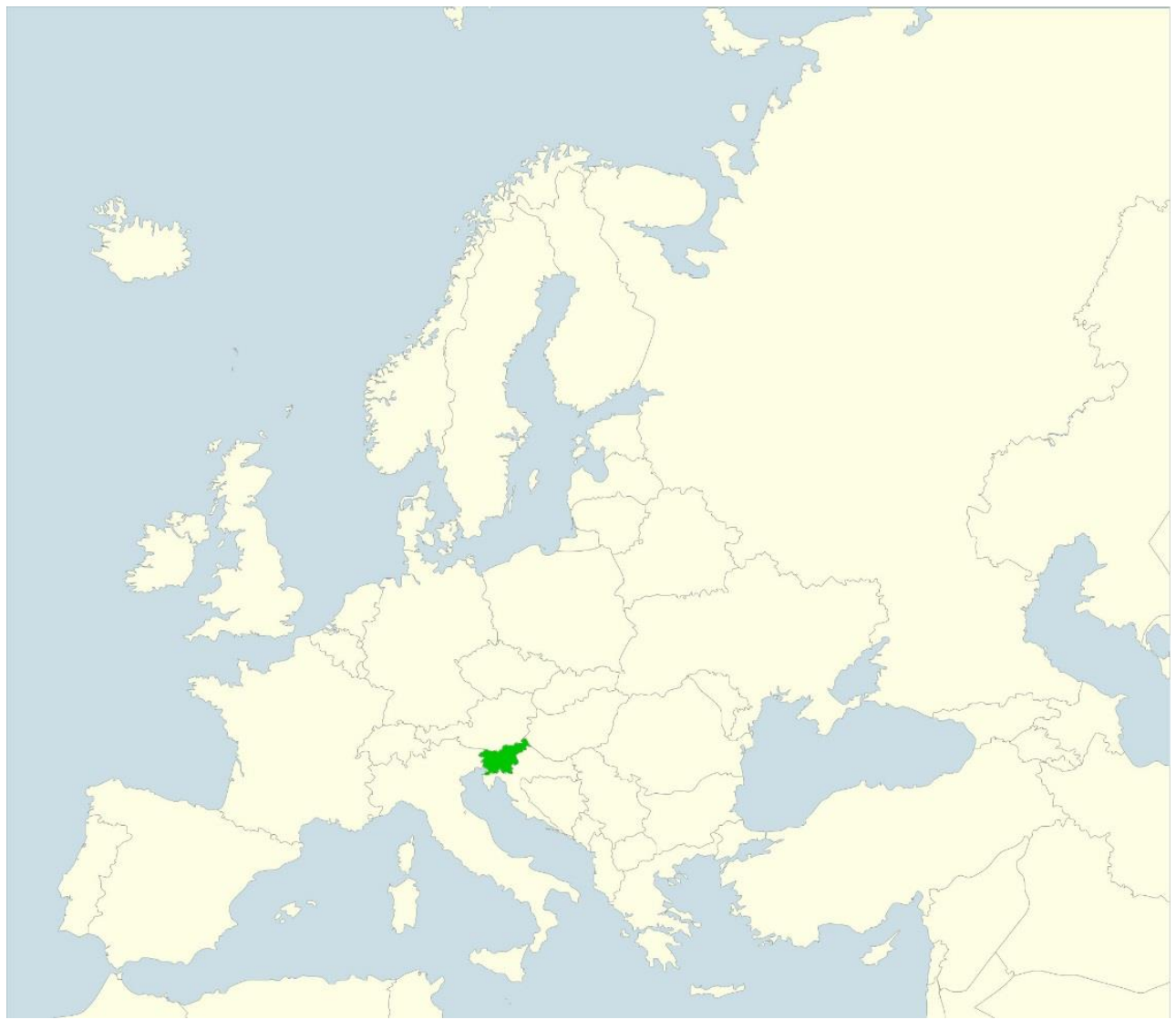

\footnotetext{
1 Jennifer Deriaz, ESAIP Engineering School, Saint-Barthélemy-d'Anjou, France, ORCID: 0000-0002-9894-8531, e-mail: jenniferderiaz@gmail.com

${ }^{2}$ dr. Rok Ciglič, Research Centre of the Slovenian Academy of Sciences and Arts, Anton Melik Geographical Institute, Slovenia, ORCID: 0000-0003-3517-3780; e-mail: rok.ciglic@zrc-sazu.si

${ }^{3} \mathrm{dr}$. Mateja Ferk, Research Centre of the Slovenian Academy of Sciences and Arts, Anton Melik Geographical Institute, Novi trg 2, SI - 1000 Ljubljana, Slovenia, ORCID: 0000-0003-0145-7590, e-mail: mateja.ferk@zrc-sazu.si

${ }^{4}$ dr. Dénes Loczy, Institute of Geography and Earth Sciences, Faculty of Sciences, University of Pécs, Hungary, ORCID: 0000-0002-2542-6775; e-mail: loczyd@gamma.ttk.pte.hu
} 
Abstract: In several European countries, land use changes can be analysed on the basis of the Franciscan Cadastre. Present land use data is defined on the basis of orthophotos, but the historical data is available only at a parcel level. Therefore, a question arose as to how reliable results about land use changes can be. The main aim of the paper was to analyse land use dynamics with the Franciscan Cadastre and to test the compatibility of detailed and parcel level of modern data. The study was carried out by calculating land use structure and landscape metrics for a part of the Pannonian low-hills area in Slovenia. We have observed that the calculation of the land use type structure mostly provided similar results regardless of the level of detail. On the other hand, the results of landscape metrics analysis were highly affected by the level of detail. The analysis at the parcel level showed that the forest area expanded, and fields and vineyards areas diminished. In general, today's landscape is made of less patches, but they are larger and of more irregular shapes. We can conclude that a comparison of modern data and historical data based on Franciscan Cadastre must include generalisation to a parcel level.

Key words: geography, land use data, land use change, landscape metrics, geomorphology, Franciscan Cadastre

Izvleček: Spremembe $\mathrm{v}$ rabi tal lahko $\mathrm{v}$ številnih evropskih državah analiziramo na osnovi franciscejskega katastra. Podatki o današnji rabi tal so definirani na osnovi ortofotov, zgodovinski viri pa so na voljo le na ravni parcele. Zato se pojavi vprašanje o zanesljivosti rezultatov analize spreminjanja rabe tal. Glavni namen prispevka je bil analizirati spreminjanje rabe tal $s$ pomočjo franciscejskega katastra in preizkusiti združljivost detajlne in parcelne ravni sodobnih podatkov. Študija je bila izvedena z računanjem strukture rabe tal in pokrajinskih metrik za del panonskih gričevij v Sloveniji. Ugotovili smo, da je izračun strukture tipov rabe tal podoben, ne glede na raven natančnosti podatka. Hkrati pa smo ugotovili, da so rezultati analize pokrajinskih metrik močno odvisni od ravni natančnosti. Analiza na ravni parcel je pokazala, da se je površina gozdov povečala, površina njiv in vinogradov pa se je zmanjšala. Današnja pokrajina ima v splošnem manj zaplat, ki pa so večji in bolj nepravilnih oblik. Zaključimo lahko z ugotovitvijo, da je pri primerjavi današnjih podatkov in zgodovinskih podatkov, ki temeljijo na franciscejskem katastru, nujno treba vključiti posplošitev podatkov na raven parcele.

Ključne besede: geografija, podatki o rabi tal, spreminjanje rabe tal, pokrajinska metrika, geomorfologija, Franciscejski kataster

\section{Introduction}

The reorganisation of human activities is increasingly transforming the landscape, particularly since industrialisation began in the late $18^{\text {th }}$ to early $19^{\text {th }}$ century: growth of large urbanised centres during the industrial period, and deconcentration of population and suburbanisation in the post-industrial period (Kokole, 1969; Carter, 1990). Throughout the world, built-up areas were expanding (Hall \& Hay, 1980; Ravbar, 1995; Bourne, 1996; Rebernik, 2004) and the socio-economic changes of the society are reflected in the land use patterns and trends (Lopez et al,. 1988; Klink \& Moreira 2002; Larson et al., 2001; Wu, 2008). With varying land use practices, the dynamics of natural (geomorphological) processes is changing as well, impacting especially microclimatic conditions and hydrological processes; e.g., variability of soil temperatures and moisture, runoff, erosion rates, sediment yield etc. (Wolman, 1967; Graf, 1975; Sala \& Inbar, 1992; Filoso et al., 2006; Mohapatra et al., 2014). 
There is much evidence of land use change in the landscape (Dupouey et al., 2002). A comparison of current and past conditions can give us information about the dynamics (changes and trends) of a landscape. Additionally, it can provide an insight into the structure of historical land use, which might have been more ecologically orientated than at present. In general, the deforestation leads to faster water run-off, and vice-versa vegetated areas are capable of retaining a higher amount of water upstream and preventing floods downstream (Graf, 1975; Bystřický et al., 2017). Analysis of past land use can provide useful insight on how to steer landscape management, e.g., how to direct land use towards more resilient and sustainable form in order to prevent flooding (Doležal et al., 2018).

Past landscapes can be analysed on the basis of historical land use maps (cadastres, registers) and other maps. In the case of countries (including Slovenia) that were part of the Habsburg Empire and later Austro-Hungarian Empire, there are numerous land use maps of Franciscan Cadastre available. The Franciscan Cadastre was prepared for all of the Slovenian territory between 1818 and 1828 (Drobnik, 2002; Golec, 2010), and revised between 1869 and 1887 (Seručnik, 2009). This makes it possible to compare today's land use (available as a digital land use layer) with a situation approximately 150-200 years ago. Such comparison is also possible in other countries with Franciscan Cadastre, e.g., Austria (Lisec \& Navratil 2014). With landscape metrics tools it is also possible to upgrade visual comparison and analyse land use data for a modern and a historical situation and provide quantitative comparison between both states.

Various papers have been published dealing with the present land use and/or land use in $19^{\text {th }}$ century. Some of them analysed tabular data, some provided visual comparison, and some conducted geospatial analysis (Petek \& Urbanc, 2004; Tlapáková et al., 2013; Szturc et al., 2017; Gabrovec \& Kumer, 2019). For spatial analysis, extensive georeferencing and manual digitisation are needed. Present land use data are precisely defined (digitised) on the basis of orthophoto images, but the historical data are available only at a parcel level. Therefore, a question of comparability with modern techniques also arises, e.g.: how comparable are land use structures and how reliable are landscape metrics calculations?

The aim of this paper is two-fold. The first goal is to analyse land use structure and landscape metrics for both contemporary and historical landscape in the Pannonian low-hills area. The case study area is located in Jareninski Potok watershed in Slovenske Gorice, NE Slovenia. Namely, there has not been any similar detailed spatial and landscape metric analysis of land use in this region done yet. Since the greatest ecological problems in a wider area are landslides and flooding, the results of the research can inform us how the landscape changed in the last two centuries, especially from the water retention capabilities point of view.

The second goal is methodologically oriented. Since the historical cadastral land use data are available only at a parcel level and the modern data are available at more precise level (as digitised orthophotos), the research strives to test different spatial levels for analysing land use structure and landscape metrics. In order to compare both land use statuses (in the first half of $19^{\text {th }}$ century and in the year 2018) appropriately, the contemporary (2018) data were generalised to the parcel level. However, calculations with original contemporary (non-generalised) data were also performed in order to simulate the difference between both ways of calculations and assess the influence of the data preparation on the research results.

\section{Research area}

The Slovenske Gorice is a hilly region in northeast Slovenia and a part of the western rim of the Pannonian Basin. The hills are formed in Miocene marl rocks and up to $400 \mathrm{~m}$ high, the valleys are flattened in fluvial sediments at about $250 \mathrm{~m}$ a.s.I. (Žnidarčič \& Mioč, 1987). The continental climate in the region brings about $900 \mathrm{~mm}$ of precipitation per year (Ogrin, 1998). Despite the gentle slope inclinations, the marl rocks are susceptible to weathering and landslides are common. As an adaptation to natural processes, the infrastructure (e.g., roads, settlements) is focused at the top of the ridges. For agricultural purposes, many of the slopes were traditionally stabilised by building 
cultural terraces for vineyards and orchards (Pipan \& Kokalj, 2017). Valley floors, prone to flooding, were meliorated and are used for fields.

The case study was carried out in the catchment of Jareninski Potok stream situated in the northwest of the Slovenske Gorice (Figure 1). The stream is approximately $9 \mathrm{~km}$ long and drains an area of $9.2 \mathrm{~km}^{2}$. The catchment is divided into 5 cadastral municipalities: Vajgen, Jareninski Vrh, Jareninski Dol, Polički Vrh and southern part of Šentilj.

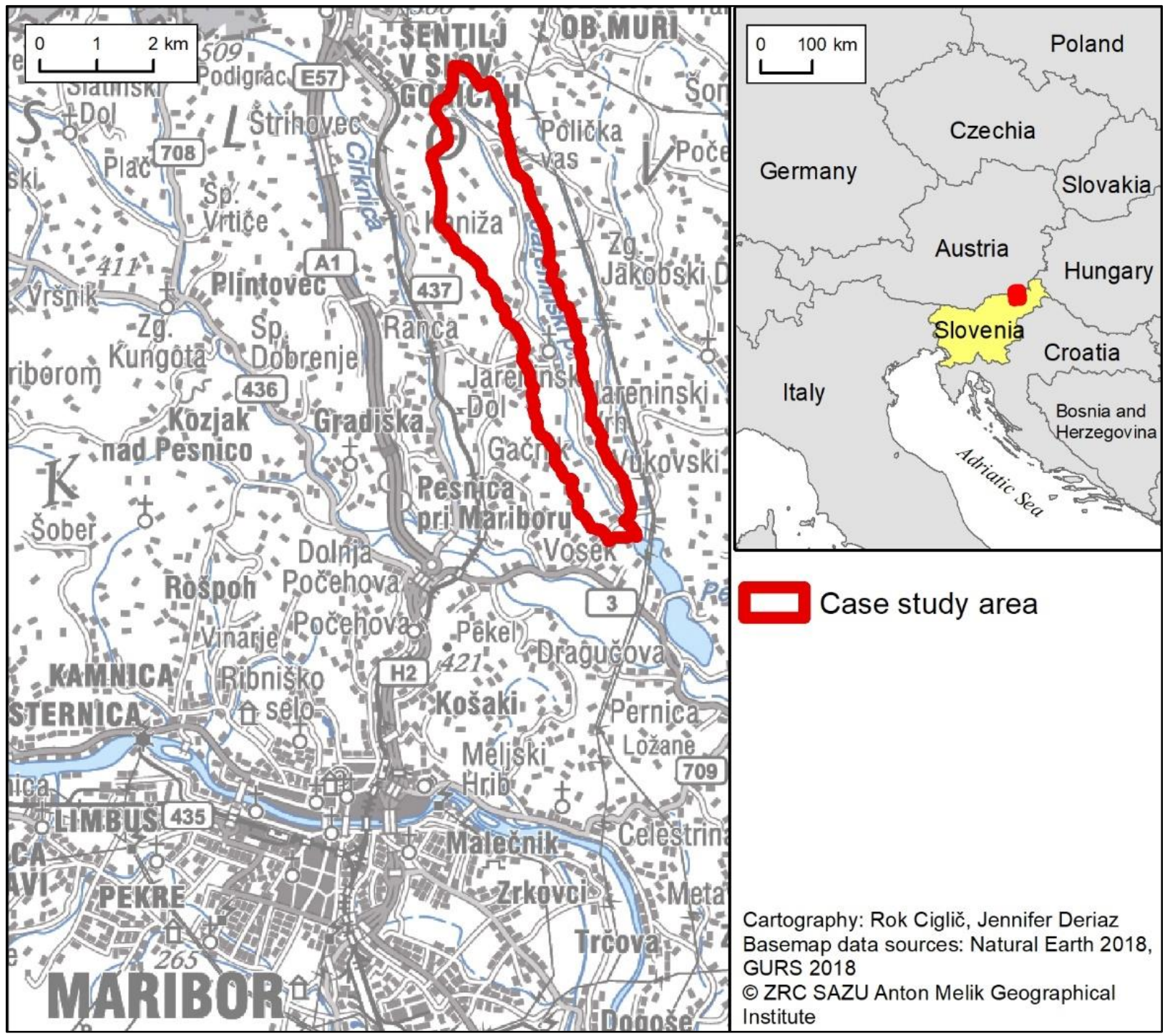

Fig 1. Overview map.

For the hilly landscape of the Slovenske Gorice, modified remnants of historical agricultural practices, overgrowing of pastures and abandonment of cultural terraces is characteristic in present time (Pipan \& Kokalj, 2017). The area experienced vigorous political and economic changes during the last two centuries; i.e., the region was part of the Austro-Hungarian Empire, State of Slovenes, Croats and Serbs, Kingdom of Serbs, Croats and Slovenes, Kingdom of Yugoslavia, Third Reich (German occupation), Federal People's Republic of Yugoslavia, Socialist Federal Republic of Yugoslavia, Republic of Slovenia, successively (Borak et al., 2006). Dynamic historical events make the area an excellent example for studying land use changes. 


\section{Data and methods}

\subsection{Data layers and their preparation}

The analysis was based on the following databases:

- Franciscan Land Use Cadastre for 1824 provided by The Archives of the Republic of Slovenia,

- Land Use Database (digitised orthophotos) for 2018 provided by Ministry of Agriculture, Forestry, and Food,

- Land Cadastre (parcels) for 2018 provided by The Surveying and Mapping Authority of the Republic of Slovenia for 2018,

- $\quad$ LIDAR Database (Laser scanning data) provided by Slovenian Environment Agency.

The maps of the Franciscan Cadastre were used as the source of historical land use data (Figure 2). For each cadastral municipality in the Jareninski Potok watershed (municipalities: Vajgen, Jareninski Vrh, Jareninski Dol, Polički Vrh, Šentilj), the corresponding scanned images (200 dpi) of the cadastre were selected. The scale of these maps is 1:2880. They show land use types at the parcel level using both colours and symbols. The land use types represented in our area of interest are: forests, meadows (with and without trees or bushes), pastures (with and without trees or bushes), vineyards, fields, buildings, courtyards and gardens.

The first step consisted of geo-referencing the scanned images of the Franciscan Cadastre (previously merged by municipality), using ground control points evenly distributed and defined by locations or objects easily identifiable (e.g., parcel borders, tripoints). The digitising was then done manually, storing polygons for the parcels of each municipality in a dedicated feature class, included in a geodatabase. Once the digitising was completed, topological rules were defined to check the topology of the polygon layers that were created: the goal was to make sure that there were no gaps within the layers and that none were overlapping. The polygon layers by municipality were then merged in a single layer for the whole watershed, and an additional topology check followed.

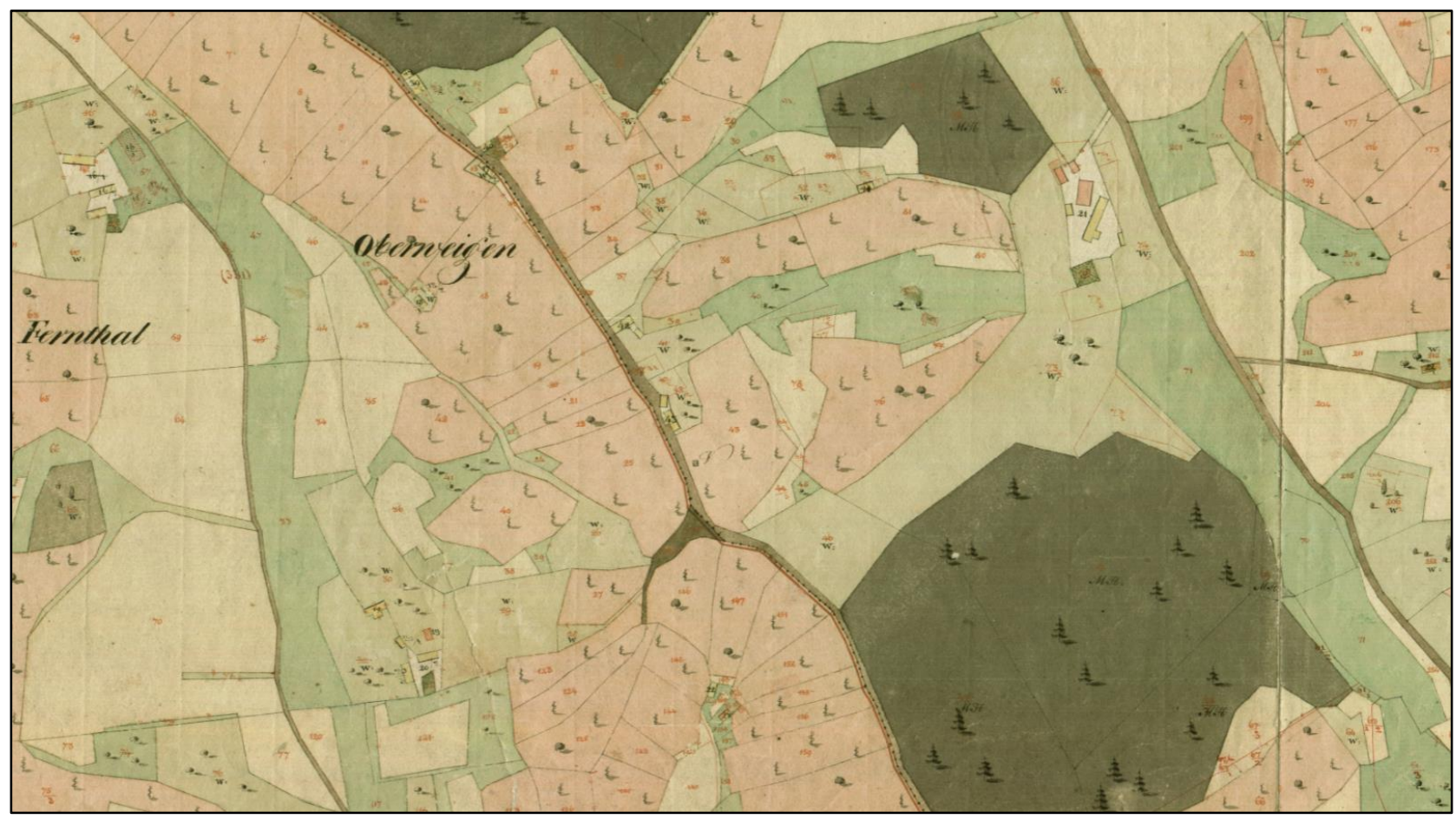

Fig 2. Original image of Franciscan Cadastre, showing a part of Vajgen municipality [Gemeinde Weigen]. 
The land use data for 2018 were provided as land use database by Ministry of Agriculture, Forestry, and Food. This database was established for the whole country in 2002 and has been constantly updated. The main source for the land use database is digitalisation of orthophotos; however, field work and other sources (e.g., farm register data, aerial images, and topography maps) are also included in order to provide correct land use type (Miličić \& Udovč, 2012). The database is available in a digital vector format.

Land Cadastre (with modern parcel polygons) for 2018 was also available in a digital vector format. Therefore, no additional preparation steps for these two data layers were needed.

Laser scanning dataset presenting ground points was available in zLAS format. In order to prepare raster layers of relief features (elevation and slope), the conversion to las dataset and interpolation of point data was necessary. We prepared a digital elevation model with a resolution of $5 \mathrm{~m}$.

\subsection{Definition of land use categories}

There were some differences between land use categorisation in $19^{\text {th }}$ century and land use categorisation in $21^{\text {st }}$ century. Therefore, in order to make the land use comparison possible, it was necessary to define a simplified land use categorisation for both years. We strived to make a clear difference between the areas that are vegetated, either with grass, trees, or vines, and the ones without vegetation or built-up. Such differentiation can show a ratio between areas that are capable of higher water retention and prevent land sliding (e.g., vegetated areas) and areas that have less ability of water retention and accelerate land slide occurrence (e.g., built-up areas, fields). Namely, these are one of the main characteristics of the area under consideration. The simplified level for Franciscan Cadastre is presented in Table 1. When simplifying Franciscan Cadastre, two parcels were not identified and hence classified as "unknown or non-vegetated".

Tab 1. List of original land use classes and respective land use classes at simplified level (merging classes) for Franciscan Cadastre (1824).

\begin{tabular}{|l|l|}
\hline \multicolumn{1}{|c|}{ Original level } & Simplified level \\
\hline building & built-up \\
\hline courtyard & built-up \\
\hline field & field \\
\hline forest & forest \\
\hline garden & field \\
\hline meadow & grassland \\
\hline meadow with bushes & individual trees \\
\hline meadow with trees & Individual trees \\
\hline pasture & grassland \\
\hline pasture with bushes & individual trees \\
\hline pasture with trees & individual trees \\
\hline road & built-up \\
\hline vineyard & vineyard \\
\hline vineyard with bushes & vineyard \\
\hline vineyard with trees & vineyard \\
\hline unknown or non-vegetated & unknown or non-vegetated \\
\hline
\end{tabular}

When simplifying Land Use Database for 2018 (Table 2) two categories, "water" and "wetland", appeared. These were not present on the Franciscan Cadastre in the area studied. Hence, we included them in the "unknown or non-vegetated" category. Both categories represent only a small portion of the area (approximately $0.5 \%$ ). 
Tab 2. List of original land use classes and respective land use classes at simplified level (merging classes) for Land Use Database (2018).

\begin{tabular}{|l|l|}
\hline \multicolumn{1}{|c|}{ Original level } & \multicolumn{1}{c|}{ Simplified level } \\
\hline arable land & field \\
\hline other permanent crops on arable land & field \\
\hline green houses & field \\
\hline vineyards & vineyard \\
\hline intensive orchards & individual trees \\
\hline extensive orchards & individual trees \\
\hline other permanent crops & individual trees \\
\hline meadows and pastures & grassland \\
\hline overgrown areas & individual trees \\
\hline riparian overgrowth, forest hedges and groups of trees and bushes & forest \\
\hline $\begin{array}{l}\text { temporarily uncultivated agriculture land (natural grassland, fallow land, } \\
\text { land within fenced pastures for pigs, horses, etc. where grass is } \\
\text { trampled by animals, land in preparation for vineyards, meadows,...) }\end{array}$ & field \\
\hline forest trees on agricultural land & individual trees \\
\hline forest & forest \\
\hline built-up areas and related surfaces & built-up \\
\hline other marshy areas & unknown or non-vegetated \\
\hline waters & unknown or non-vegetated \\
\hline
\end{tabular}

\subsection{Preparation of contemporary land use data at parcel level}

Since the land use data for 2018 was acquired by digitisation of orthophotos and improved with additional sources (including field observation), the level of precision is much higher than the one obtained from digitizing the Franciscan Cadastre. In our case, it might be more relevant to standardise the level of land use detail according to the level available in 1824, that is, the parcel level. Therefore, the land use for 2018 was re-calculated at the (generalised) parcel level, keeping only the most represented land use type for each parcel (Figure 3). For example, if vineyard was the prevailing land use at a certain parcel, this land use type (vineyard) was defined to the entire parcel. However, both levels for 2018 are used in the following calculations (comparison with 1824) and can thus be compared in order to follow the second main goal of the paper. 


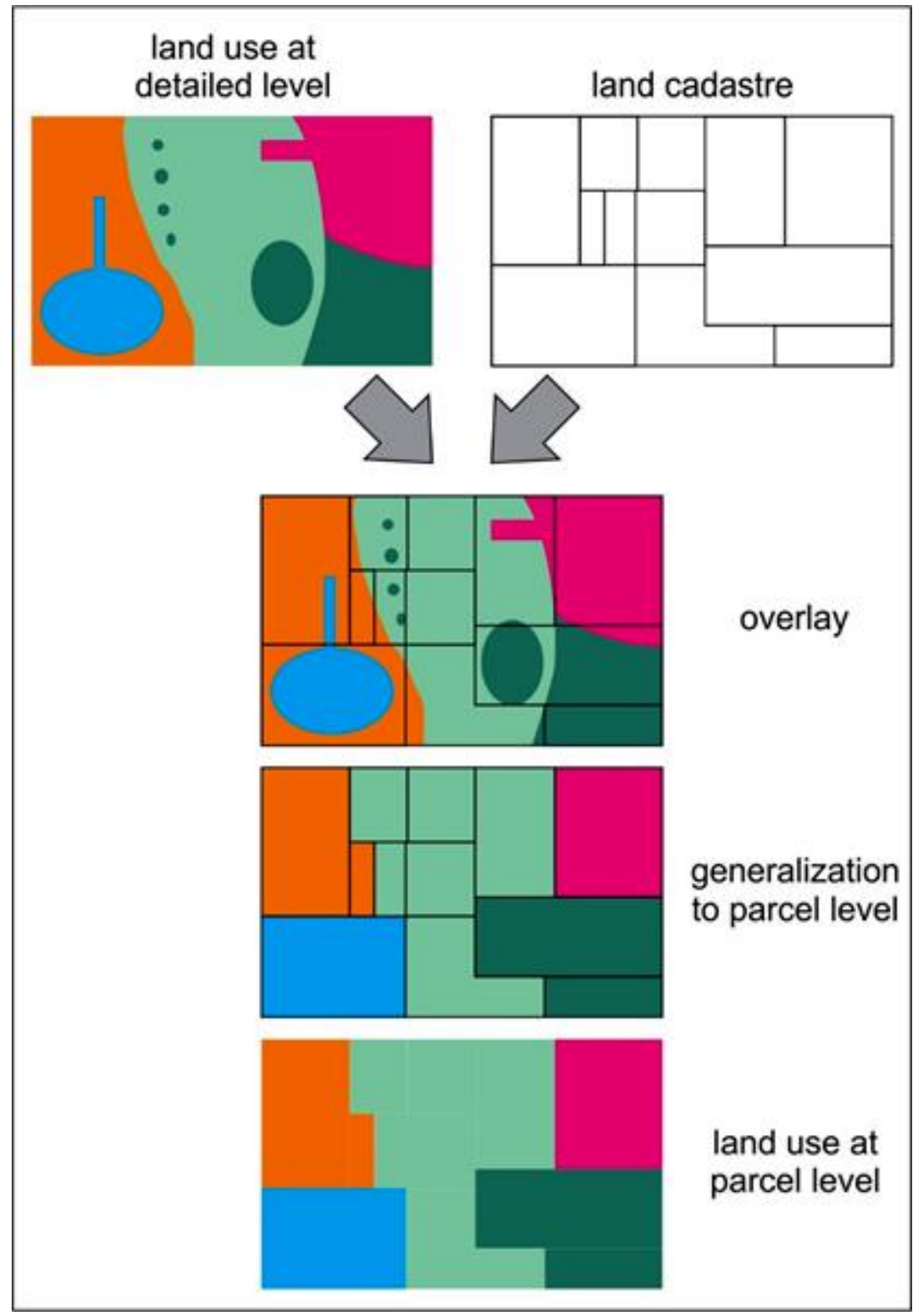

Fig 3. A methodology for determination of modern (2018) land use at parcel level.

\subsection{Land use analysis}

All the land use datasets (land use in 1824 at parcel level; land use in 2018 at detailed level; and land use in 2018 at parcel level) were analysed according to geometrical and geomorphological characteristics.

The first part of geometrical analysis was dedicated to basic land use structure. Area for each class and its proportion were calculated and land use changes between 1824 and 2018 were analysed. More detailed geometrical analysis followed. Landscape metrics (Table 3) were generated using Patch Analyst Software, with shape files of the land use from the $19^{\text {th }}$ century and $21^{\text {st }}$ century as inputs. Landscape metrics were computed by class (describing land use configuration) and by landscape (describing land use composition). 
Tab 3. Landscape metrics used in the land use analysis.

\begin{tabular}{|l|l|}
\hline \multicolumn{1}{|c|}{ Landscape metric (abbrev.) } & \multicolumn{1}{c|}{ Short description } \\
\hline number of Patches (NumP) & Number of patches (polygons). \\
\hline mean Patch Size (MPS) & Mean area of all patches (polygons). \\
\hline total Edge (TE) & Sum of the lengths of all edges of the patches. \\
\hline mean Perimeter-Area Ratio (MPAR) & Mean ratio of the patch perimeter over area. \\
\hline area Weighted Mean Shape Index (AWMSI) & $\begin{array}{l}\text { Level of complexity of shape, a higher value indicates a higher } \\
\text { deviation from a square. The mean for all patches is weighted by } \\
\text { their area. }\end{array}$ \\
\hline $\begin{array}{l}\text { area Weighted Mean Patch Fractal Dimension } \\
\text { (AWMPFD) }\end{array}$ & $\begin{array}{l}\text { Mean ratio of perimeter per unit area, weighted by the area of } \\
\text { the patch. Indicates the irregularity of the patch shape. }\end{array}$ \\
\hline patch Size Standard Deviation (PSSD) & Spread of the patch size. \\
\hline Shannon's Diversity Index (SDI)* & $\begin{array}{l}\text { Diversity of landscape, between 0 (no diversity) and 1 (high } \\
\text { diversity). }\end{array}$ \\
\hline Shannon's Evenness Index (SEI)* & $\begin{array}{l}\text { Measure of area composition and richness, between 0 (one class } \\
\text { dominates the area) and 1 (all classes are present in equal } \\
\text { proportions). }\end{array}$ \\
\hline
\end{tabular}

${ }^{*}$ calculated only at a landscape level

Geomorphological analysis was made in order to observe general changes in land use in relation to the main relief characteristic - slope. The average slope was hence computed by type of land use for both years - 1824 and 2018. The analysis was based on $5 \mathrm{~m}$ elevation model. Such coarse resolution was chosen due to several reasons. Due to the lack of $19^{\text {th }}$ century DEM, it was decided to conduct the analysis on coarser model. In this way, terraced and non-terraced areas had more averaged (gentle) slope, which shows the main long-term characteristic of certain hilly area, regardless of the micro characteristics (e.g., terraces, roads ...). Additionally, elevation models produced at lower resolutions had a lot of noise (especially in overgrown areas).

\section{Results and discussion}

\subsection{Analysis of basic structure of land use}

The land use structure change from 1824 to 2018 shows similar evolutions when compared at the detailed level as well as compared at the parcel level (Table 4; Figure 4).

Tab 4. Land use structure for 1824 and 2018.

\begin{tabular}{|c|c|c|c|c|c|c|}
\hline \multirow[b]{2}{*}{ Land use type } & \multicolumn{3}{|c|}{ Area (ha) } & \multicolumn{2}{|c|}{ Change } & \multirow{2}{*}{$\begin{array}{l}\text { Difference } \\
\text { between } \\
\text { detailed and } \\
\text { parcel level } \\
\text { (detailed } \\
\text { level is } \\
\text { a basis) }\end{array}$} \\
\hline & 1824 & $\begin{array}{c}2018 \\
\text { (detailed) }\end{array}$ & $\begin{array}{c}2018 \\
\text { (by } \\
\text { parcel) }\end{array}$ & $\begin{array}{c}\text { Percentage } \\
\text { change } \\
\text { (detailed) }\end{array}$ & $\begin{array}{c}\text { Percentage } \\
\text { change (by } \\
\text { parcel) }\end{array}$ & \\
\hline built-up & 26.24 & 63.89 & 56.79 & $143 \%$ & $116 \%$ & $-11 \%$ \\
\hline field & 231.22 & 210.17 & 212.66 & $-9 \%$ & $-8 \%$ & $1 \%$ \\
\hline forest & 123.40 & 191.62 & 186.03 & $55 \%$ & $51 \%$ & $-3 \%$ \\
\hline grassland & 197.81 & 302.16 & 311.81 & $53 \%$ & $58 \%$ & $3 \%$ \\
\hline individual trees & 141.39 & 94.54 & 94.51 & $-33 \%$ & $-33 \%$ & $0 \%$ \\
\hline $\begin{array}{l}\text { unknown or } \\
\text { non-vegetated }\end{array}$ & 1.20 & 4.82 & 4.33 & $302 \%$ & $261 \%$ & $-10 \%$ \\
\hline vineyard & 196.46 & 50.51 & 51.58 & $-74 \%$ & $-74 \%$ & $2 \%$ \\
\hline
\end{tabular}




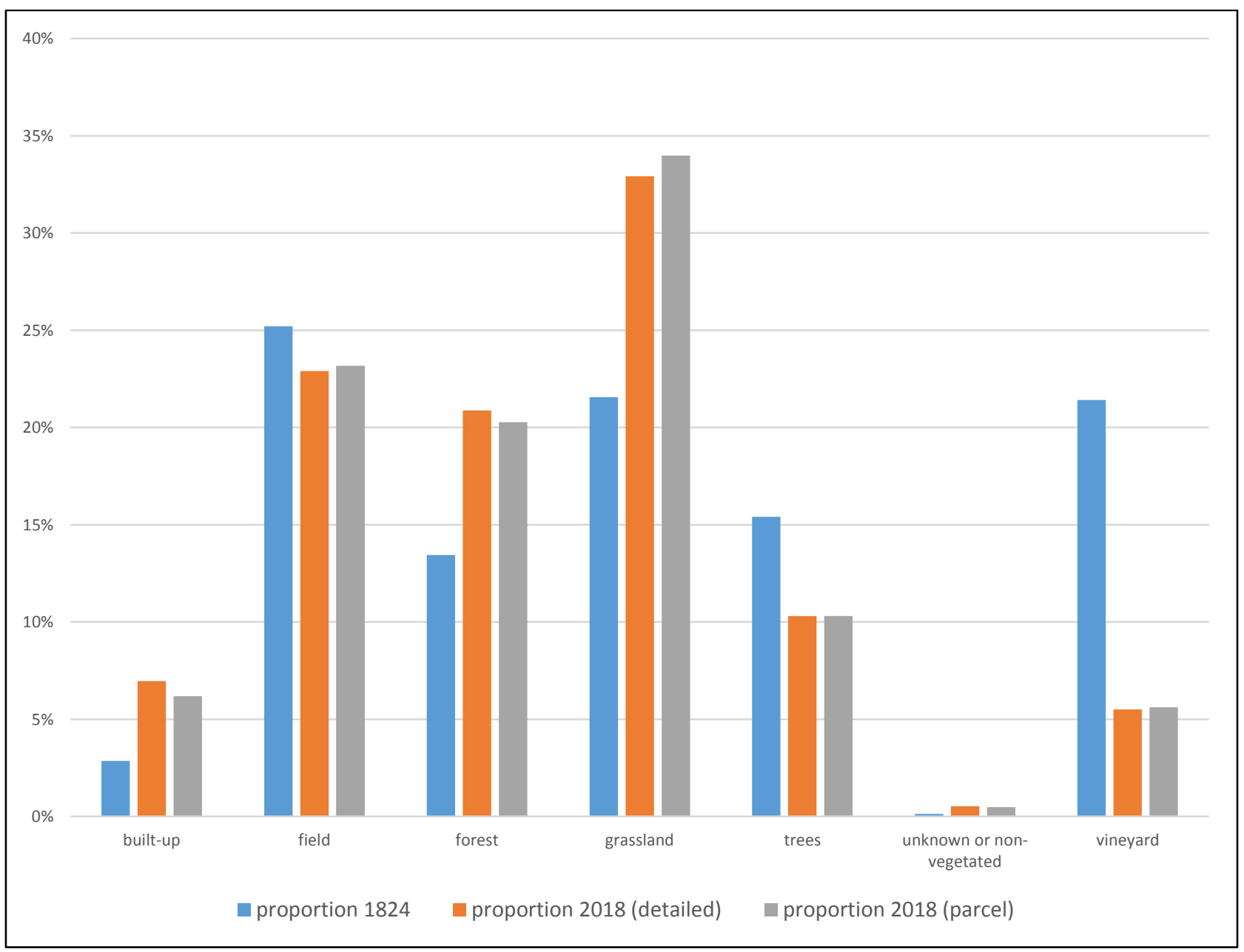

Fig 4. Proportion of land use types (\% of total area).

Built-up areas (buildings and roads) increased the most $(+143 \%$ at the detailed level, $+116 \%$ at the parcel level). Forests and grasslands have also increased (more than $+50 \%$ for both, at both level of precision), whereas land use types related to an active agricultural use, such as fields and vineyards, have decreased. The most dramatic decline is related to the latter category: the area dedicated to the vineyards has been reduced by $74 \%$. These changes in landscapes can be seen also when comparing land use maps for both years (Figure 5). The vineyards went from representing $21 \%$ of the area of the landscape to only about $5 \%$. The number of patches has decreased, and so has the median patch size (Tables 7 and 8). Unknown or non-vegetated is not so relevant for this comparison, since in 2018, it includes categories such as water and wetland too, and represents only a small portion of the landscape, between 0.1 and $0.5 \%$.

The built-up areas went from less than $3 \%$ of the landscape to more than $6 \%$ (Figure 6). Hence, even though they have seen the biggest increase, they remain a weakly represented land use type. It is interesting to note though that, in 2018, they represent a bigger proportion of the landscape than vineyards do. 


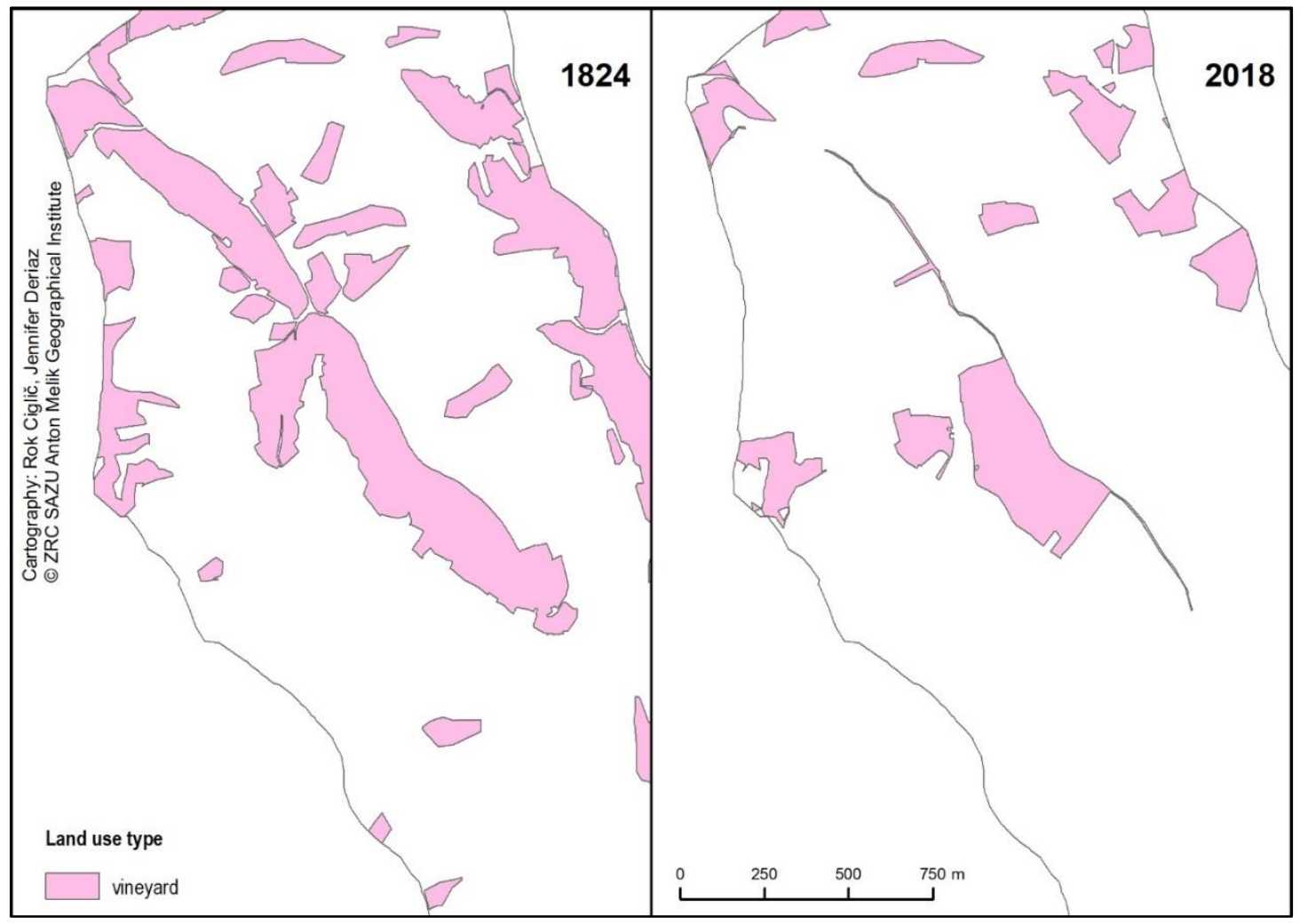

Fig 5. Area covered by vineyards diminished by $74 \%$. An example of Vajgen area (left: year 1824; right: year 2018, parcel level).

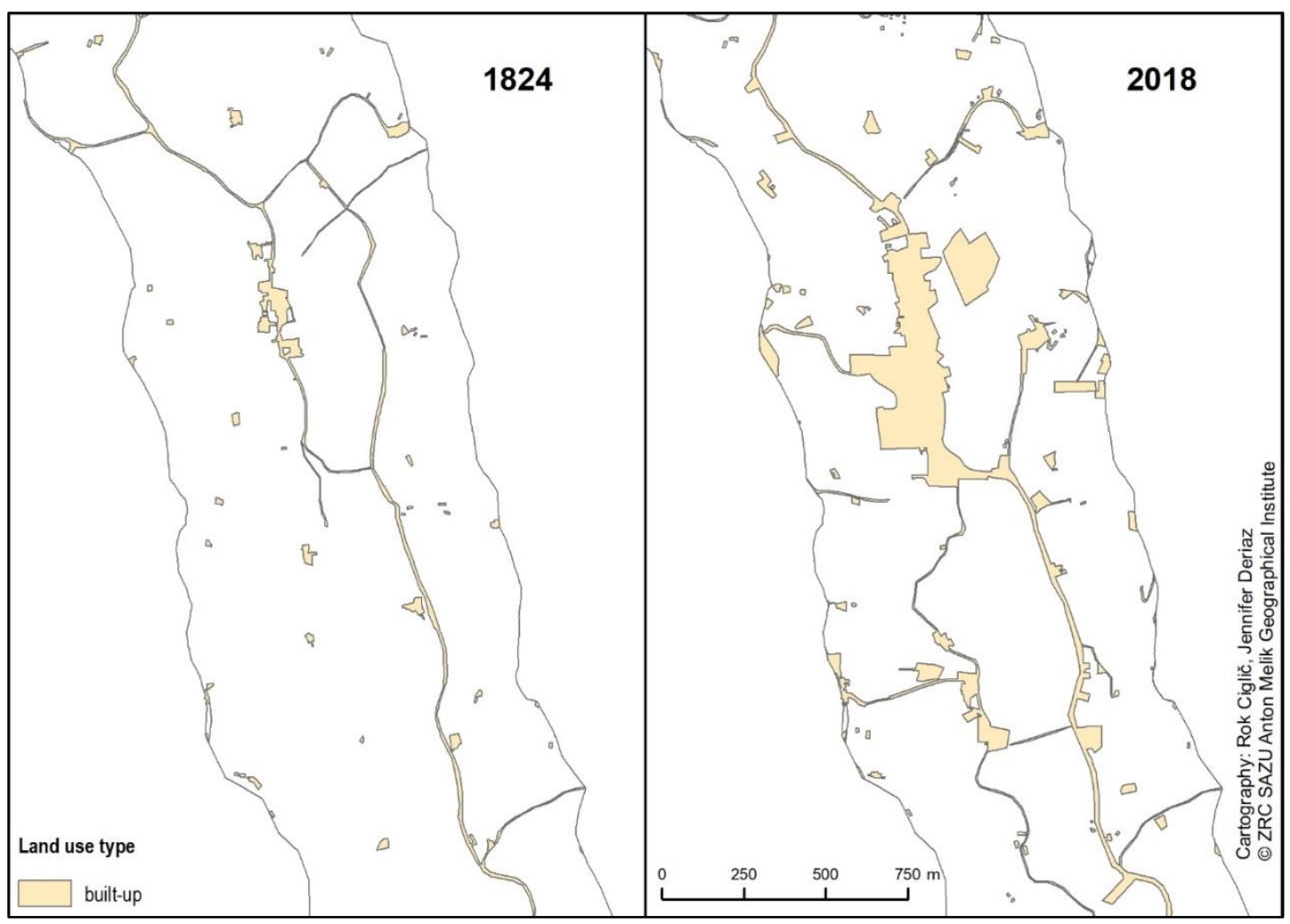

Fig 6. Built-up areas have increased their share. An example of the Jareninski Dol (left: year 1824; right: year 2018, parcel level). 
The built-up land use type shows in a way lower number of patches (at both 2018 levels), which could suggest the extension of some areas that in the end form one big patch instead of multiple spread out patches (Tables 7 and 8). This could be compatible with the fact that the patch size standard deviation is way higher even though the mean patch size is lower.

Both methods for land use area calculation (detailed and parcel level) provide similar results and therefore are mostly not strongly influenced by the land use data detail level. However, there is an exception. Built-up class data for 2018 are quite different if we calculate areas at the detailed level or at the parcel level. Calculation based at parcel level gives much lower value (approximately 10\%) than calculation at detailed level.

\subsubsection{Analysis of geomorphometric characteristics of land use changes}

It can be observed that the mean slope between 1824 and 2018 increased for the categories builtup, forest, grassland, and individual trees (Table 5). Both field and vineyard land use types have seen a decrease in their mean slope. Forest areas constitute the steepest areas in 2018 whereas in 1824, vineyards had the steepest mean slope. Results of both land use 2018 dataset (detailed and parcel level) are similar.

Tab 5. Mean slope change between 1824 and 2018.

\begin{tabular}{|c|c|c|c|c|}
\hline \multirow{2}{*}{ Land use type } & \multicolumn{3}{|c|}{ Mean slope (degrees) } & \multirow{2}{*}{$\begin{array}{l}\text { Percentage change } \\
\text { 1824-2018 (by parcel) }\end{array}$} \\
\hline & 1824 & 2018 (detailed) & 2018 (by parcel) & \\
\hline built-up & 8.85 & 8.79 & 9.11 & $3 \%$ \\
\hline field & 11.16 & 7.13 & 7.12 & $-57 \%$ \\
\hline forest & 18.97 & 20.48 & 20.26 & $6 \%$ \\
\hline grassland & 8.61 & 12.21 & 12.52 & $31 \%$ \\
\hline individual trees & 8.11 & 16.47 & 16.03 & $49 \%$ \\
\hline vineyard & 20.93 & 19.29 & 19.13 & $-9 \%$ \\
\hline
\end{tabular}

Vineyards in 1824 had a mean slope of almost 21 degrees, and about 2 degrees less in 2018. The ones that were overgrown (replaced with individual trees or forests) have a mean slope of almost 23 degrees. The maximum slope is also reduced, from 50 degrees in 1824 to 47 degrees in 2018 (Table 6). Thus, it seems that the vineyards that were abandoned were first and foremost the steepest ones. A potential reason for that seems to be that vineyards on the steepest slopes in the past were enabled by the cultural terraces. Due to non-existence of $19^{\text {th }}$ century DEM, this cannot be fully confirmed. However, modernisation and especially mechanisation of agriculture after the $2^{\text {nd }}$ World War definitely led to the abandonment of the terraces because of their inadequacy for modern techniques (e.g., the terraces were too narrow for the new machines). Furthermore, with the improved economy, the labour force became too expensive for manual handling of vineyards (Pipan \& Kokalj, 2017).

Tab 6. Slope change for vineyards.

\begin{tabular}{|l|r|r|r|r|r|}
\hline & \multicolumn{5}{|c|}{ Slope (degrees) } \\
\cline { 2 - 6 } & Minimum value & Maximum value & Range & Mean & Standard deviation \\
\hline 1824 vineyards & 0.12 & 50.81 & 50.69 & 20.93 & 7.59 \\
\hline overgrown vineyards & 0.30 & 50.81 & 50.52 & 22.73 & 8.05 \\
\hline 2018 vineyards (by parcel) & 0.19 & 47.14 & 46.95 & 19.13 & 7.19 \\
\hline
\end{tabular}

${ }^{*}$ Refers to the vineyards in 1824 that became individual trees or forests in 2018. 


\subsection{Analysis of landscape metrics}

Majority of the metrics between 1824 and 2018 changed at least for more than several tens or even at $100 \%$. The only exception is Area weighted mean patch fractal dimension (AWMPFD), which did not change as much as the others. In this case (AWMPFD), also both levels (detailed and parcel level) do not differ as much as other metrics.

Tab 7. Comparison of landscape metrics between 1824 and 2018 (detailed level) - class analysis.

\begin{tabular}{|c|c|c|c|c|c|c|}
\hline \multirow[b]{2}{*}{ Land use type } & \multicolumn{3}{|c|}{ Number of Patches (NumP) } & \multicolumn{3}{|c|}{ Mean Patch Size (MPS) } \\
\hline & 1824 & $\begin{array}{c}2018 \\
\text { (detailed) }\end{array}$ & $\begin{array}{l}\text { Percentage } \\
\text { change }\end{array}$ & 1824 & $\begin{array}{c}2018 \\
\text { (detailed) }\end{array}$ & $\begin{array}{l}\text { Percentage } \\
\text { change }\end{array}$ \\
\hline built-up & 199 & 177 & $-11.06 \%$ & 0.13 & 0.36 & $173.76 \%$ \\
\hline field & 269 & 378 & $40.52 \%$ & 0.86 & 0.56 & $-35.31 \%$ \\
\hline forest & 31 & 134 & $332.26 \%$ & 3.98 & 1.43 & $-64.08 \%$ \\
\hline grassland & 202 & 186 & $-7.92 \%$ & 0.98 & 1.62 & $65.89 \%$ \\
\hline individual trees & 81 & 198 & $144.44 \%$ & 1.75 & 0.48 & $-72.65 \%$ \\
\hline $\begin{array}{l}\text { unknown or non- } \\
\text { vegetated }\end{array}$ & 2 & 17 & $750.00 \%$ & 0.60 & 0.28 & $-52.68 \%$ \\
\hline vineyard & 78 & 66 & $-15.38 \%$ & 2.52 & 0.77 & $-69.62 \%$ \\
\hline \multirow[b]{2}{*}{ Land use type } & \multicolumn{3}{|c|}{ Total Edge (TE) } & \multicolumn{3}{|c|}{ Mean Perimeter-Area Ratio (MPAR) } \\
\hline & 1824 & $\begin{array}{c}2018 \\
\text { (detailed) }\end{array}$ & $\begin{array}{l}\text { Percentage } \\
\text { change }\end{array}$ & 1824 & $\begin{array}{c}2018 \\
\text { (detailed) }\end{array}$ & $\begin{array}{l}\text { Percentage } \\
\text { change }\end{array}$ \\
\hline built-up & 64503.90 & 112838.00 & $74.93 \%$ & 4752.40 & 8915.28 & $87.60 \%$ \\
\hline field & 106996.00 & 99785.30 & $-6.74 \%$ & 1475.59 & 7912.07 & $436.20 \%$ \\
\hline forest & 26974.60 & 62836.00 & $132.95 \%$ & 555.41 & 4722.72 & $750.31 \%$ \\
\hline grassland & 121192.00 & 185654.00 & $53.19 \%$ & 3244.24 & 18143.50 & $459.25 \%$ \\
\hline individual trees & 64308.90 & 86579.60 & $34.63 \%$ & 1122.22 & 3413.58 & $204.18 \%$ \\
\hline $\begin{array}{l}\text { unknown or non- } \\
\text { vegetated }\end{array}$ & 606.93 & 3806.28 & $527.14 \%$ & 679.32 & 3522.19 & $418.49 \%$ \\
\hline vineyard & 61290.00 & 21104.60 & $-65.57 \%$ & 1508.01 & 2321.95 & $53.97 \%$ \\
\hline \multirow{2}{*}{ Land use type } & \multicolumn{3}{|c|}{$\begin{array}{l}\text { Area Weighted Mean Shape Index } \\
\text { (AWMSI) }\end{array}$} & \multicolumn{3}{|c|}{$\begin{array}{c}\text { Area Weighted Mean Patch Fractal } \\
\text { Dimension (AWMPFD) }\end{array}$} \\
\hline & 1824 & $\begin{array}{c}2018 \\
\text { (detailed) }\end{array}$ & $\begin{array}{l}\text { Percentage } \\
\text { change }\end{array}$ & 1824 & $\begin{array}{c}2018 \\
\text { (detailed) }\end{array}$ & $\begin{array}{l}\text { Percentage } \\
\text { change }\end{array}$ \\
\hline built-up & 18.00 & 27.99 & $55.50 \%$ & 1.70 & 1.71 & $0.63 \%$ \\
\hline field & 1.59 & 1.67 & $5.06 \%$ & 1.35 & 1.35 & $0.07 \%$ \\
\hline forest & 2.03 & 2.17 & $6.67 \%$ & 1.33 & 1.35 & $1.89 \%$ \\
\hline grassland & 3.33 & 3.73 & $12.15 \%$ & 1.45 & 1.46 & $1.27 \%$ \\
\hline individual trees & 2.63 & 2.41 & $-8.23 \%$ & 1.40 & 1.44 & $2.85 \%$ \\
\hline $\begin{array}{l}\text { unknown or non- } \\
\text { vegetated }\end{array}$ & 1.16 & 1.86 & $60.79 \%$ & 1.32 & 1.38 & $5.04 \%$ \\
\hline vineyard & 2.16 & 1.44 & $-33.55 \%$ & 1.36 & 1.33 & $-2.35 \%$ \\
\hline
\end{tabular}


We noticed that calculation of landscape metrics and its comparison between 1824 and 2018 at land use class level is highly influenced by the land use database for 2018 (see Tables 7 and 8). Namely, results based on detailed level and parcel level differ. There were some examples where the calculation based at detail level and parcel level resulted also in the direction of change (positivenegative), e.g., number of patches (in the case of field class), mean patch size (field), total edge (individual trees), area weighted mean shape index (built-up, grassland), and area weighted mean patch fractal dimension (grassland, individual trees, vineyard).

According to the parcel level comparison (Table 8; which we regard as more relevant, since the 1824 land use data is based at the parcel level), we noticed that the number of patches diminished and their average size increased for fields and grasslands. On the contrary, forest and individual trees now have more patches with lower average size. This means they are more fragmented. A number of patches with vineyards decreased and the individual size of patches shrunk. Built-up areas have now more patches and also their size increased on average.

Built-up areas and especially forest increased their total edge length. That means that they have smaller patches and/or that patch shapes are very irregular.

Total edge decrease and the smallest increase of mean perimeter-area ratio for fields, individual trees and vineyards show that these patches are less complex. All the values of area weighted mean shape index (AWMSI) are higher than one, confirming that the patches have irregular shapes. Vineyards have the lowest AWMSI. We can assume that only intensely cultivated vineyards with regular shapes are used. The area weighted mean patch fractal dimension (AWMPFD) changed less in comparison to other metrics.

According to the parcel level, analysis of metrics for the entire research area (Table 9) shows a decrease in number of patches (NumP) and total edge (TE), and an increase in mean patch size (MPS), area weighted mean shape index (AWMSI), mean perimeter-area ratio (MPAR) and area weighted mean patch fractal dimension (AWMPFD). This shows that the area is made of less patches, but they are larger and of more complex and irregular shapes than in the past. On the other hand, results that are based on detailed level show an increase in number of patches (NumP) and decrease in mean patch size (MPS). Also, total edge (TE) is higher. This is simply a consequence of more detailed input data (digitized orthophotos) that provide much more details than parcel level.

Shannon's diversity index (SDI) and Shannon's evenness index (SEI) decreased by 2-3\% for both 2018 levels (detailed and parcel level), which indicates in modern landscape a lower diversity and equality of distribution of the various land use types. For instance, it appears that in 2018, grasslands constitute an important part of the landscape (about one-third of the total area) whereas in 1824, there were three land use types (field, grassland and vineyard) that each represented around 20$25 \%$ of the landscape area.

The comparison between the two levels of precision for 2018 shows little difference ( $2 \%$ or less) on SEI, SDI and AWMPFD. NumP is lower at the parcel level and the MPS is higher, since it was simplified to only keep the most represented land use type for each parcel. MPAR is more than twice higher at the parcel level of detail, which indicates that the patches at the parcel level have a higher amount of areas exposed to edges shared with other types of land use. 
Tab 8. Comparison of landscape metrics (by class) between 1824 and 2018 (parcel level).

\begin{tabular}{|c|c|c|c|c|c|c|}
\hline \multirow{2}{*}{$\begin{array}{l}\text { Land use } \\
\text { type }\end{array}$} & \multicolumn{3}{|c|}{ Number of Patches (NumP) } & \multicolumn{3}{|c|}{ Mean Patch Size (MPS) in hectares } \\
\hline & 1824 & $\begin{array}{c}2018 \\
\text { (by parcel) }\end{array}$ & $\begin{array}{l}\text { Percentage } \\
\text { change }\end{array}$ & 1824 & $\begin{array}{c}2018 \\
\text { (by parcel) }\end{array}$ & $\begin{array}{l}\text { Percentage } \\
\text { change }\end{array}$ \\
\hline built-up & 199 & 248 & $24.62 \%$ & 0.131845 & 0.229009 & $73.70 \%$ \\
\hline field & 269 & 131 & $-51.30 \%$ & 0.859536 & 1.62333 & $88.86 \%$ \\
\hline forest & 31 & 82 & $164.52 \%$ & 3.98069 & 2.26863 & $-43.01 \%$ \\
\hline grassland & 202 & 163 & $-19.31 \%$ & 0.979272 & 1.91292 & $95.34 \%$ \\
\hline $\begin{array}{l}\text { individual } \\
\text { trees }\end{array}$ & 81 & 133 & $64.20 \%$ & 1.74556 & 0.710631 & $-59.29 \%$ \\
\hline $\begin{array}{l}\text { unknown or } \\
\text { non- } \\
\text { vegetated }\end{array}$ & 2 & 3 & $50.00 \%$ & 0.599374 & 1.44234 & $140.64 \%$ \\
\hline vineyard & 78 & 43 & $-44.87 \%$ & 2.51866 & 1.19964 & $-52.37 \%$ \\
\hline \multirow{2}{*}{$\begin{array}{l}\text { Land use } \\
\text { type }\end{array}$} & \multicolumn{3}{|c|}{ Total Edge (TE) in metres } & \multicolumn{3}{|c|}{ Mean Perimeter-Area Ratio (MPAR) } \\
\hline & 1824 & $\begin{array}{c}2018 \\
\text { (by parcel) }\end{array}$ & $\begin{array}{l}\text { Percentage } \\
\text { change }\end{array}$ & 1824 & $\begin{array}{c}2018 \\
\text { (by parcel) }\end{array}$ & $\begin{array}{l}\text { Percentage } \\
\text { change }\end{array}$ \\
\hline built-up & 64503.9 & 83133.1 & $28.88 \%$ & 4752.4 & 20789.7 & $337.46 \%$ \\
\hline field & 106996 & 69683.5 & $-34.87 \%$ & 1475.59 & 2277.89 & $54.37 \%$ \\
\hline forest & 26974.6 & 53401.7 & $97.97 \%$ & 555.409 & 9071.15 & $1533.24 \%$ \\
\hline grassland & 121192 & 129979 & $7.25 \%$ & 3244.24 & 43696.5 & $1246.89 \%$ \\
\hline $\begin{array}{l}\text { individual } \\
\text { trees }\end{array}$ & 64308.9 & 61206.1 & $-4.82 \%$ & 1122.22 & 1673.01 & $49.08 \%$ \\
\hline $\begin{array}{l}\text { unknown or } \\
\text { non- } \\
\text { vegetated }\end{array}$ & 606.931 & 1453.4 & $139.47 \%$ & 679.323 & 1174.26 & $72.86 \%$ \\
\hline vineyard & 61290 & 21587.9 & $-64.78 \%$ & 1508.01 & 2591.86 & $71.87 \%$ \\
\hline \multirow{2}{*}{$\begin{array}{l}\text { Land use } \\
\text { type }\end{array}$} & \multicolumn{3}{|c|}{$\begin{array}{l}\text { Area Weighted Mean Shape Index } \\
\text { (AWMSI) }\end{array}$} & \multicolumn{3}{|c|}{$\begin{array}{l}\text { Area Weighted Mean Patch Fractal Dimension } \\
\text { (AWMPFD) }\end{array}$} \\
\hline & 1824 & $\begin{array}{c}2018 \\
\text { (by parcel) }\end{array}$ & $\begin{array}{l}\text { Percentage } \\
\text { change }\end{array}$ & 1824 & $\begin{array}{c}2018 \\
\text { (by parcel) }\end{array}$ & $\begin{array}{l}\text { Percentage } \\
\text { change }\end{array}$ \\
\hline built-up & 18.00 & 15.67 & $-12.93 \%$ & 1.70 & 1.62 & $-4.14 \%$ \\
\hline field & 1.59 & 1.77 & $11.00 \%$ & 1.35 & 1.34 & $-0.66 \%$ \\
\hline forest & 2.03 & 2.14 & $5.31 \%$ & 1.33 & 1.35 & $1.63 \%$ \\
\hline grassland & 3.33 & 3.16 & $-5.05 \%$ & 1.45 & 1.41 & $-2.39 \%$ \\
\hline $\begin{array}{l}\text { individual } \\
\text { trees }\end{array}$ & 2.63 & 2.29 & $-13.05 \%$ & 1.40 & 1.40 & $-0.14 \%$ \\
\hline $\begin{array}{l}\text { unknown or } \\
\text { non- } \\
\text { vegetated }\end{array}$ & 1.16 & 1.42 & $22.82 \%$ & 1.32 & 1.32 & $-0.07 \%$ \\
\hline vineyard & 2.16 & 2.02 & $-6.36 \%$ & 1.36 & 1.36 & $0.38 \%$ \\
\hline
\end{tabular}


Tab 9. A comparison of landscape metrics, between 1824 and 2018 (detailed) and between 1824 and 2018 (by parcel) landscape analysis.

\begin{tabular}{|c|c|c|c|c|c|c|}
\hline Landscape metric & 1824 & $\begin{array}{c}2018 \\
\text { (detailed) }\end{array}$ & $\begin{array}{l}\text { Percentage } \\
\text { change } \\
\text { (detailed) }\end{array}$ & $\begin{array}{l}2018 \text { (by } \\
\text { parcel) }\end{array}$ & $\begin{array}{l}\text { Percentage } \\
\text { change (by } \\
\text { parcel) }\end{array}$ & $\begin{array}{c}\text { Difference } \\
\text { between } \\
2018 \\
\text { (detailed) } \\
\text { and } 2018 \\
\text { (by parcel) }\end{array}$ \\
\hline $\begin{array}{l}\text { Shannon's Diversity Index } \\
\text { SDI }\end{array}$ & 1.68 & 1.64 & $-2.33 \%$ & 1.62 & $-3.21 \%$ & $-1 \%$ \\
\hline $\begin{array}{l}\text { Shannon's Evenness Index } \\
\text { SEI }\end{array}$ & 0.86 & 0.84 & $-2.33 \%$ & 0.83 & $-3.21 \%$ & $-1 \%$ \\
\hline $\begin{array}{l}\text { Area Weighted Mean Shape } \\
\text { Index AWMSI }\end{array}$ & 2.78 & 4.35 & $56.74 \%$ & 3.24 & $16.83 \%$ & $-25 \%$ \\
\hline $\begin{array}{l}\text { Mean Perimeter-Area Ratio } \\
\text { MPAR }\end{array}$ & 2581.32 & 8187.98 & $217.20 \%$ & 17008.80 & $558.92 \%$ & $108 \%$ \\
\hline $\begin{array}{l}\text { Area Weighted Mean Patch } \\
\text { Fractal Dimension } \\
\text { AWMPFD }\end{array}$ & 1.39 & 1.42 & $2.46 \%$ & 1.39 & $0.29 \%$ & $-2 \%$ \\
\hline Total Edge TE & 445872.00 & 572604.00 & $28.42 \%$ & 420445.00 & $-5.70 \%$ & $-27 \%$ \\
\hline Mean Patch Size MPS & 1.06 & 0.79 & $-25.43 \%$ & 1.14 & $7.35 \%$ & $44 \%$ \\
\hline Number of Patches NumP & 862.00 & 1156.00 & $34.11 \%$ & 803.00 & $-6.84 \%$ & $-31 \%$ \\
\hline
\end{tabular}

\subsection{Land use and its ecological value assessment}

The increase of built-up areas has a negative impact on hydrological conditions since it increases the water runoff and causes faster accumulation of water in the lowest parts of the valley, which leads to a higher flood risk in such areas. However, according to the Bystřický et al. (2017), the increase of forested areas has a positive impact on water retention (e.g., trees increase the evapotranspiration of water). Also, the proportion of fields has diminished and the proportion of grassland has risen. The proportion of land use types such as forest and individual trees (and also grasslands) today is higher than in the $19^{\text {th }}$ century. These types have denser vegetation cover and can retain water better than fields, which are exposed to soil erosion. Similar observation of landscape transformation was also reported by Pipan \& Kokalj (2017) for other parts of the Pannonian Hills in Slovenia. In the past, vineyards were set at the steepest areas, but at present, forests cover the steepest parts of the watershed. Such relationship is also better for soil preservation and water retention.

\subsection{Methodological issues}

Certain issues emerged after conducting the research at two levels (detailed and parcel). As far as proportions of land use types are concerned, it appears there isn't such a big difference between the comparisons with both levels of 2018 (the exception is built-up area). Also, a comparison with other work done on the past structure of the landscape from the tabular part of the Franciscan Cadastre (e.g., Gabrovec \& Kumer, 2019) is in agreement with the results obtained in this study.

The main methodological issue that was unveiled during the research is connected with the level of detail of the data used for landscape metrics analysis. Since $19^{\text {th }}$ century data is only available at the parcel level, we have to take that fact into account when comparing it to the contemporary (highly detailed) data. As already mentioned, we have noticed that the calculation of the structure of land use types provides quite similar results regardless of the level (results for detailed and parcel level were alike), the largest difference was observed for built-up areas. However, results of landscape metrics analysis were highly affected by the input data (results for detailed and parcel level were different). Altogether 49 indices (Tables 7, 8, 9) were calculated and 18 cases differ by the direction(!) 
of change (positive/negative). Therefore, land use comparison between historical and modern situation must be made at the same data level. Some past analysis did not clearly present the level of detail for their research (e.g., Tlapáková et al., 2013; Szturc et al., 2017). The analysis at the parcel level seems to be more relevant and in our case, it showed that the landscape diversity diminished. In general, modern landscape is made of less patches, but they are larger and of more complex and irregular shapes.

Another issue is related to the geomorphological analysis. Namely, digital elevation model is only available for $21^{\text {st }}$ century. Therefore, we cannot assume about the exact terrain structure 200 years ago. With currently available spatial data, it is not possible to check, whether a certain place was terraced or not in $19^{\text {th }}$ century. Therefore, definite conclusion regarding land use change and its connection to the terrain remains open for discussion. For more detailed study, one should also include other non-spatial sources, e.g., drawings, text records, field work.

\section{Conclusion}

This paper focused on evaluating the changes in land use for the Jareninski Potok watershed in Slovenske Gorice (NE Slovenia), between 1824 and 2018. Additionally, we assessed two different levels of data precision to analyse land use evolutions.

The first goal was to analyse land use structure and landscape metrics for both historical and contemporary landscape for the area of Jareninski Potok watershed. The overall trend shows that vineyards are the land use type that underwent the most dramatic decline in area, whereas built-up areas have grown the most. Regarding vineyards, it can be suggested that a steeper slope is linked to a higher rate of abandonment. In general, modern landscape is made of less patches, but they are larger and of more complex and irregular shapes. However, the diversity of land uses is lower than in the past. The increase in urbanised areas may have a negative effect according to water retention and flood prevention management, but the increase in forest and individual trees areas may bring a positive impact, allowing better permeability of the soil, vegetation water retention, and diminishing land sliding.

Since the 2018 land use database provides more detailed information than historical (from 1824), we generalised modern data in order to secure more suitable comparison. Thus, all the calculations of modern land use structure and landscape metrics were made twice. It appeared that both datasets (data based on precise digitization from orthophotos and data based on generalisation of data to a parcel level) show similar results when evaluating basic landscape structure (proportions of land use types), but more complex landscape metrics can greatly vary depending on the selected level of precision. We observed that the basic database preparation highly influences this part of the results. Therefore, a landscape metrics comparison of modern and historical land use data based on Franciscan Cadastre must take into account the fact that generalisation to a parcel level is needed.

Since the Franciscan land cadastre is available for several European countries, it would be worth to repeat the study for other areas with different land use data sources and to compare the results with original and generalized data layers. Such studies could provide additional insight into, how modern data are (in)comparable to the historical.

\section{Acknowledgement}

The authors acknowledge the study was financially supported by the Slovenian Research Agency (Possible ecological control of flood hazard in the hilly regions of Hungary and Slovenia, N6-0070; Geography of Slovenia, P6-0101) and National Research, Development and Innovation Office (NKFIH, contract no SNN 125727). 
[1] Borak, N., Čepič, Z., Fischer, J., Deželak-Barič, V., Dolenc, E., Gabrič, A., Gašparič, J., Godeša, B., Guštin, D., Kresal, F., Lazarević, Ž., Mlakar, B., Pančur, A., Perovšek, J., Prinčič, J., Režek, M., Studen, A., Šorn, M., Tominšek Čehulić, T., Troha, N., Vidovič-Miklavčič, A., Vodopivec, P., Ferenc, T., Kacin-Wohinz, M., Kandus, N., Zemljič, I. \& Rihtaršič, M. (2006). Slovenska novejša zgodovina: od programa Zedinjena Slovenija do mednarodnega priznanja Republike Slovenije: 1848-1992. Ljubljana: Mladinska knjiga, Inštitut za novejšo zgodovino.

[2] Bourne, L. S. (1996). Reinventing the Suburbs: Old Myths and New Realities. Progress in Planning 46(3), 163-184. DOI: 10.1016/0305-9006(96)88868-4.

[3] Bystřický, V., Moravcová, J., Polenský, J. \& Pečenka, J. (2017). Land use changes in the last half century and their impact on water retention in the Šmava mountains and foothills (Czech Republic). European Countryside 9(1), 116-131. DOI: 10.1515/euco-2017-0007.

[4] Carter, H. (1990). Urban and Rural Settlements. London: Longman.

[5] Doležal, P., Konečná, J., Karásek, P., Podhrázská, J. \& Pochop, M. (2018). Water Retention in a Small Agricultural Catchment and its Potential Improvement by Design of Water Reservoirs A Case Study of the Bílý Potok Catchment (Czechia). European Countryside 10(1), 1-22. DOI: 10.2478/euco-2018-0001.

[6] Drobenik, M. (2002). Reproduciranje franciscejskega katastra Arhivi 25(2), 65-76.

[7] Dupouey, J.-L., Dambrine, E., Laffite, J.-D. \& Moares, C. (2002). Irreversible Impact of Past Land Use on Forest Soils and Biodiversity. Reports Ecology 83(11), 2978-2984. DOI: $10.2307 / 3071833$.

[8] Filoso, S., Martinelli, L. A., Howarth, R. W., Boyer, E. W. \& Dentener, F. (2006). Human activities changing the nitrogen cycle in Brazil. In Martinelli, L. A. \& Howarth, R. W., eds., Nitrogen Cycling in the Americas: Natural and Anthropogenic Influences and Controls (pp. 61-89). Dordrecht: Springer. DOI: 10.1007/978-1-4020-5517-1_4.

[9] Gabrovec, M. \& Kumer, P. (2019). Land-use changes in Slovenia from the Franciscean Cadaster until today. Acta Geographica Slovenica 59(1), 63-81. DOI: 10.3986/AGS.4892.

[10] Golec, B. (2010). Zemljiški katastri 18. in 19. stoletja kot vir za stavbno, gradbeno in urbanistično zgodovino slovenskega ozemlja, 2. del Arhivi 33(2), 339-396.

[11] Graf, W. L. (1975). The Impact of Suburbanization on Fluvial Geomorphology. Water Resources Research (11-5), 690-692. DOI: 10.1029/WR011i005p00690.

[12] Hall, P. \& Hay, D. (1980). Growth Centres in the European Urban System. London: Heinemann Educational Publishers.

[13] Klink, C. A. \& Moreira, A. G. (2002). Past and current human occupation and land use. In Oliveira, P. S. \& Marquin, R. J., eds., The Cerrados of Brazil: ecology and natural history of a neo-tropical savannah, New York: Columbia University Press.

[14] Lisec, A. \& Navratil, G. (2014). The Austrian land cadastre: from the earliest beginnings to the modern land information system. Geodetski vestnik 58(3), 482-516. DOI: 10.15292/geodetski-vestnik.2014.03.482-516.

[15] Kokole, V. (1969). Urbanizacija podeželja v Sloveniji. Geografski vestnik 41, 3-23.

[16] Larson, J., Findeis, J. \& Smith, S. (2001). Agricultural adaptation to urbanization in southeastern Pennsylvania. Agricultural and Resource Economics Review 30(1), 32-43. DOI: $10.1017 / S 1068280500000526$. 
[17] Lopez, R. A., Adelaja, A. O. \& Andrews, M. S. (1988). The effects of suburbanisation on agriculture. American Journal of Agricultural Economics 70(2), 346-358. DOI: 10.2307/1242075.

[18] Miličić, V. \& Udovč, A. (2012). Uporabnost prostorskih podatkov kmetijskega sektorja za analize sprememb kmetijskih zemljišč na primeru izbranega območja varovanja narave v Sloveniji. Geodetski vestnik 56(1), 83-104. DOI: 10.15292/geodetski-vestnik.2012.01.083-104.

[19] Mohapatra, S. N., Pani, P. \& Sharma, M. (2014). Rapid Urban Expansion and Its Implications on Geomorphology: A Remote Sensing and GIS Based Study. Geography Journal 1(10), 1-10. DOI: $10.1155 / 2014 / 361459$.

[20] Ogrin, D. (1998). Podnebje. In Fridl, J., Kladnik, D., Orožen Adamič, M., Perko, D., eds., Geografski atlas Slovenije: Država v prostoru in času. (pp. 110-111). Ljubljana: DZS.

[21] Petek, F. \& Urbanc, M. (2004). The Franziscean Land Cadastre as a Key to Understanding the $19^{\text {th }}$-century Cultural Landscape in Slovenia. Acta Geographica Slovenica 44, 89-113. DOI: $10.3986 / A G S 44104$.

[22] Pipan, P. \& Kokalj, Ž. (2017). Transformation of the Jeruzalem Hills cultural landscape with modern vineyard terraces. Acta Geographica Slovenica 57(2), 149-162. DOI: 10.3986/AGS.4629.

[23] Ravbar, M. (1995). Zasnova poselitve v Sloveniji. Ljubljana: Inštitut za geografijo.

[24] Rebernik, D. (2004). Sodobni urbanizacijski procesi: od suburbanizacije do reurbanizacije. Geografski vestnik 76(2), 53-63.

[25] Sala, M. \& Inbar, M. (1992). Some hydrologic effects of urbanization in Catalan rivers. Catena 19(3-4), 345-361. DOI: 10.1016/0341-8162(92)90009-Z.

[26] Seručnik, M. (2009). Reambulančni kataster za Kranjsko. Kronika 57(3): 491-504.

[27] Szturc, J., Karásek, P. \& Podhrázská, J. (2017). Historical Changes in the Land Use Connected with Appropriation of Agricultural Land - Case Study of Cadastral Areas Dolní Věstonice and Modřice (Czech Republic). European Countryside 9(4), 658-678. DOI: 10.1515/euco-20170038.

[28] Tlapáková, L., Stejskalová, D., Karásek, P. \& Podhrázská, J. (2013). Landscape Metrics as a Tool for Evaluation Landscape Structure - Case Study Hustopeče. European Countryside 5(1), 52-70. DOI: 10.2478/euco-2013-0004.

[29] Wolman, M. G. (1967). A cycle of sedimentation and erosion in urban river channels. Geografiska Annaler, Series A, Physical Geography, 49(2/4): 385-395. DOI: 10.2307/520904.

[30] Wu, J. (2008). Land Use Changes: Economic, Social, and Environmental Impacts. Choices 23(4), 6-10.

[31] Žnidarčič, M. \& Mioč, P. (1987). Osnovna geološka karta SFRJ 1:100.000, list Maribor. Beograd: Zvezni geološki zavod.

Other sources

[32] Franciscan Land Use Cadastre (1824). The Archives of the Republic of Slovenia.

[33] Land Use Database (2018). Ministry of Agriculture, Forestry, and Food.

[34] Land Cadastre (2018). The Surveying and Mapping Authority of the Republic of Slovenia.

[35] LIDAR database (2018). Slovenian Environment Agency. 